\title{
The Effect of The Jigsaw Cooperative Learning Model on Student Learning Activities in Science Leassons
}

\author{
Samsul Bahri' ${ }^{1}$, Amin Mustajab ${ }^{2}$ \\ 12 STKIP Melawi, Indonesia
}

\begin{tabular}{|c|c|}
\hline (A) Check for updates open access cc) (i) (2) & DOI : 10.47400/jiees.v1i2.21 \\
\hline Sections Info & ABSTRACT \\
\hline Article history: & \multirow{10}{*}{$\begin{array}{l}\text { The science learning process is still predominantly centered on the teacher, the } \\
\text { methods and learning models are less varied. In teaching science concepts, it is } \\
\text { only obtained from the teacher so that students' insight and activity are } \\
\text { lacking. This makes the student bored, passive, and less active so that the } \\
\text { learning seem monotonous. The aim of research to determine the effect of the } \\
\text { jigsaw model of student learning activities in science lessons. The method } \\
\text { used is the experimental method, namely the experimental group and the } \\
\text { control group. The experimental group used jigsaw cooperative learning for } \\
\text { grade IVA students at SDN } 12 \text { Entikong and control class for conventional } \\
\text { learning for grade IVB students at SDN } 12 \text { Entikong. Based on the research } \\
\text { results there is an influence on jigsaw cooperative learning. It is known that } \\
\text { the value is } 3.0633,063 \mathrm{t}_{\text {count }}>\mathrm{t}_{\text {tabel }} 1,063 \text { and the average analysis is below } \\
0,866 \text { and the average is } 4,225 \text {, so that the difference in the average score is } \\
2,545 \text {. So it can be concluded that there is an influence on the application of the } \\
\text { jigsaw cooperative learning model on the learning activities of fourth grade } \\
\text { students of SDN } 12 \text { Entikong. }\end{array}$} \\
\hline Received: Oktober 082020 & \\
\hline Accepted: Oktober 102020 & \\
\hline Published online: Desember 30 & \\
\hline 2020 & \\
\hline Keywords: & \\
\hline Cooperative & \\
\hline Jigsaw & \\
\hline Activity & \\
\hline Science Leassons & \\
\hline
\end{tabular}

\section{INTRODUCTION}

The teacher-centered science learning process, the methods used do not vary, and not using learning media will result in students becoming passive, saturated, all students get the same science facts and concepts obtained only from the teacher, and students are not billed. This condition occurs because cooperative learning is not implemented optimally.

The jigsaw cooperative learning model can be applied to increase student activity in the learning process. Students are directly involved in learning and students will not behave inappropriately and interfere with the teaching and learning process. According to Wina Sanjaya (2010), activities are all student actions designed by teachers to facilitate student learning activities such as discussion activities, demonstrations, simulations, and conducting experiments. The level of student activity in learning is influenced by the strategy or teaching approach. Student activities take the form of physical, mental and intellectual activities.

Student activities in school are quite complex and varied. According to Paul D. Dierich (in Sardiman, 2014) indicators of student activity in science learning are divided into 8 activity groups including the following: (1) visual activities, (2) oral activities, (3) listening activities, (4) writing activities, (5) drawing activities, (6) motor activities, (7) mental activities dan, (8) emotional activities. The role of the teacher in learning activities there are five efforts created by the teacher to increase student learning activity according to Sumiati and Asra (2007), including the following: (1) spatial planning, (2) application of the principle of learning while doing, (3) guiding and directing students , (4) dealing with passive students, (5) attracting and maintaining students' attention to learning activities. 
Cooperative learning according to Main Sufanti (2010), is a learning system that provides opportunities for students to work together in small groups. This is confirmed by Salvin (2008) where in the cooperative class students are expected to help each other, discuss and argue with each other, hone the knowledge they master and close gaps in understanding. Cooperative learning is a strategy that places students in groups of 4-6 students with different levels of ability, gender, and background to achieve the same goal (Isjoni, 2013). The opinion of Miftahul Huda, (2014) further emphasizes that cooperative learning is able to have a significant effect on student academic achievement. So it can be concluded that cooperative learning is a learning strategy that is carried out by grouping students into small groups with heterogeneous membership characteristics to achieve the same goals.

According to Mustofa (2012), the Jigsaw Cooperative learning syntax, there are six steps or stages in learning including the following: (a) phase 1, conveying goals and motivating students, (b) phase 2, presenting information, (c) phase 3, organizing students into in cooperative groups, (d) phase 4, guiding the work and study groups, (e) phase 5, evaluation, and (f) phase 6, giving awards. The jigsaw cooperative learning model is designed to motivate students to help each other students when they master the skills or knowledge presented by the teacher. Student activities in learning must occur in groups of students. According to Maya, (2017) jigsaw cooperative learning can affect students' emotional intelligence. In addition, according to Purnomo, (2016) cooperative jigsaw can improve learning achievement.

In jigsaw cooperative learning, the teacher divides students into small groups. This is intended for maximum and effective interaction between students. The small group is the home group and the expert group. According to Agus Suprijono, (2013) The number of origin groups and expert groups depends on the concepts contained in the material to be studied. The home group is the parent group consisting of students with various abilities and backgrounds. In this home group each member has the task of learning different concepts. Each student from each home group who has the same task gathers in a new group called the expert group. Thus the expert group is a group of students who have the task of learning the same concepts. These concepts must be mastered by each member of the expert group, and these concepts will become material for their expertise. After the expert group has finished learning a certain concept, each student from this expert group returns to their home group, to teach their expertise material to their friends in a discussion group.

\section{RESEARCH METHOD}

This study used an experimental control group design without a test (Wina Sanjaya, 2010). At the end of learning the subject was not given a test and was replaced by observing the activity of the subject learning science. At the end of the study, the average science learning activity of the two groups was sought to find the difference, with the intention of knowing whether there was an effect of the learning model. The experimental group used the jigsaw cooperative learning for grade IVA students at SDN 12 Entikong and the control class for conventional learning for grade IVB students at SDN 12 Entikong.

\section{Sample / Participants / Group}


The research sample in this study were all class IVA and IVB students of SDN 12 Entikong in the odd semester of the 2019/2020 school year. Class IVA students as an experimental class using jigsaw cooperative learning totaling 22 students and class IVB as a control class totaling 20 students.

\section{Data Analysis}

The data analysis technique in this study uses the "test technique" with the formula:

$$
\mathrm{t}_{\mathrm{Obs}}=\frac{\mathrm{M}_{x}-\mathrm{M}_{y}}{\sqrt{\frac{\left(\sum x^{2}+\sum y^{2}\right)}{\left(N_{x}+N_{y}-2\right)} \mathrm{x} \frac{\left(N_{x}+N_{y}\right)}{\left(N_{x} \mathrm{x} N_{y}\right)}}}
$$

Then the results of the analysis using the formula are compared with the results of the analysis using SPSS 24

\section{RESULTS AND DISCUSSION}

The results of this study were taken from observations of learning activities in class IVA and IVB class students at SDN 12 Entikong. The experimental learning process uses jigsaw cooperative learning in class IVA and class IVB students' visual learning. In learning, it focuses more on student activities, there is a jigsaw cooperative learning process. There are eight aspects of student learning activities. Student learning aspects can be seen in table 1 .

Tabel 1. Average Value of Student Learning Activity Aspects

\begin{tabular}{clll}
\hline No & Aspek Pengamatan & $\mathbf{X}$ & $\mathbf{Y}$ \\
\hline 1 & visual activities & 3,63 & 2,76 \\
2 & oral activities & 2,82 & 3,51 \\
3 & listening activities & 3,18 & 3,32 \\
4 & writing activities & 2,89 & 1,93 \\
5 & drawing activities & 2,32 & 0,00 \\
6 & motor activities & 1,43 & 1,33 \\
7 & mental activities & 2,48 & 3,50 \\
8 & emotional activities & 2,44 & 2,71 \\
\hline
\end{tabular}

Aspects of student learning activities in the jigsaw cooperative learning experiment class and the contral class with conventional learning can be seen in graph 1.

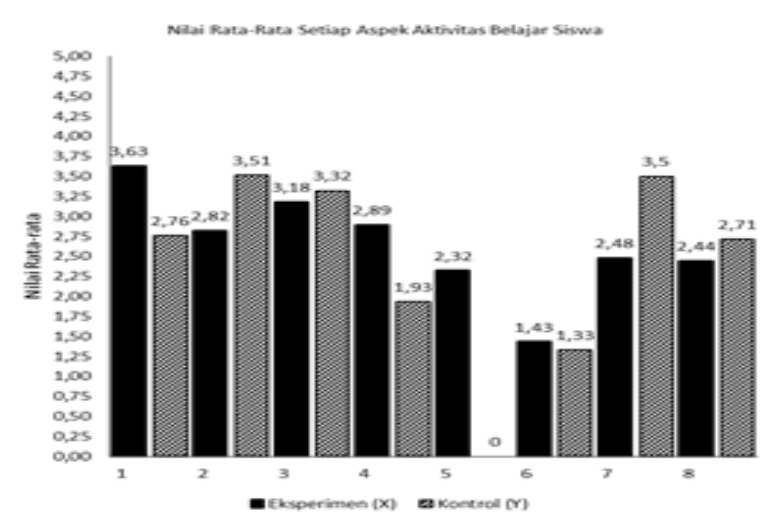

Grafik 1 Average Value of Each Aspect of Learning Activities 
Tabel 2 Description of Average Size of Student Activity

\begin{tabular}{clll}
\hline No & Deskripsi Ukuran Rata-rata & X & \multicolumn{1}{c}{ Y } \\
\hline 1 & Mean & 82,55 & 80,00 \\
2 & Median & 82,50 & 80,00 \\
3 & Mode & 84,00 & 80,00 \\
4 & Standar Dev. & 3,433 & 1,487 \\
5 & Std Err Mean & 0,732 & 0,332 \\
6 & Maksimun & 89 & 83 \\
7 & Minimun & 76 & 77 \\
8 & N & 22 & 20 \\
\hline
\end{tabular}

Hypothesis testing is done using the " $t$ " test. The results of the calculation of the " $t$ " test using the SPSS 24 program and the formula are shown in table 3 and table 4 . Based on table 3 , the conservation value is 3.063 , while the data shown in table 4 is used as a basis for determining the value of the conservation using a formula whose results are described below.

$$
\begin{aligned}
& \mathrm{t}_{\mathrm{Obs}}=\frac{\mathrm{M}_{x}-\mathrm{M}_{y}}{\sqrt{\frac{\left(\sum x^{2}+\sum y^{2}\right)}{\left(N_{x}+N_{y}-2\right)} \mathrm{x} \frac{\left(N_{x}+N_{y}\right)}{\left(N_{x} \mathrm{x} N_{y}\right)}}} \\
& \mathrm{t}_{\mathrm{Obs}}=\frac{82,55-80,00}{\sqrt{\frac{(247,45+42,00)}{(22+20-2)} \times \frac{(22+20)}{(22 \times 20)}}} \\
& \mathrm{t}_{\text {observasi }}=3,0696
\end{aligned}
$$

Based on data analysis using SPSS 24, it is known that there is a difference in the average score between the jigsaw cooperative learning model and the conventional

\begin{tabular}{|c|c|c|c|c|c|c|c|c|c|}
\hline \multicolumn{10}{|c|}{ Independent Samples Test } \\
\hline & $\begin{array}{l}\text { Leven } \\
\text { for } E q \\
\text { Var }\end{array}$ & $\begin{array}{l}e^{\prime} \text { s Tes } \\
\text { uality } \\
\text { iances }\end{array}$ & \multicolumn{7}{|c|}{ t-test for Equality of Means } \\
\hline & \multirow[t]{2}{*}{$\mathrm{F}$} & \multirow[t]{2}{*}{ Sig. } & \multirow[t]{2}{*}{$t$} & \multirow[t]{2}{*}{$D f$} & \multirow{2}{*}{$\begin{array}{c}\text { Sig. } \\
\text { (2-tailed) }\end{array}$} & \multirow{2}{*}{$\begin{array}{c}\text { Mean } \\
\text { Difference }\end{array}$} & \multirow{2}{*}{$\begin{array}{l}\text { Std. } \\
\text { Err } \\
\text { Diff }\end{array}$} & \multicolumn{2}{|c|}{$\begin{array}{c}\text { 95\% Confidence Interval } \\
\text { of the Difference }\end{array}$} \\
\hline & & & & & & & & Lower & Upper \\
\hline $\begin{array}{c}\text { Skor_A Equal } \\
\text { ktivitas variances } \\
\text { assumed }\end{array}$ & 10,920 & 002 & 3,063 & 40 & 004 & 2,545 & 831 & 0,866 & 4,225 \\
\hline $\begin{array}{l}\text { Equal } \\
\text { variances } \\
\text { not assum }\end{array}$ & & & 3,167 & 29,187 & ,004 & 2,545 & ,804 & 0,902 & 4,189 \\
\hline
\end{tabular}
method ranging from 0,866 to 4,225 with an average score difference of 2,545.

Tabel 3. Test Result " $t$ " with SPSS Program 24

Tabel 4. Data Analysis Using Formulas

\begin{tabular}{llllllll}
\hline No & Kelas & $\Sigma \mathrm{N}$ & $\Sigma \mathrm{X}$ & $\Sigma \mathrm{Y}$ & $\mathrm{M}$ & $\Sigma x^{2}$ & $\Sigma y^{2}$ \\
\hline 1 & Eksperimen & 22 & 1816 & & 82,55 & 245,45 & \\
\hline 2 & Kontrol & 20 & & 1600 & 80,00 & & 42,00 \\
\hline
\end{tabular}


Based on the experimental group, the average score of student learning activities is higher than the average score of the control group. This happened because the four aspects of student learning activities including visual aspects, writing aspects, drawing aspects, and metrics in the experimental group had a higher score than the control group. This difference is because the experimental class students are given a learning model that requires students to design their own experimental procedures according to the student worksheets on the vibrating object experiment as a source of sound and to recognize the various sounds produced from the bottles that students have received. So that each student can prepare the tools and materials independently. Meanwhile, control class students were not given the assignment to design their own experimental procedures to be carried out, so that in preparing experimental tools and materials they still depend on instructions from the teacher.

The activity of designing experiments also makes each student know how to use the tools and materials through literature study. Thus the jigsaw cooperative learning model has an effect on student learning activities. This is in line with Trianto's (2011) statement that cooperative learning can improve student performance in academic tasks. Student performance in question is none other than student learning activities, and is supported by Isjoni (2013) that in cooperative learning, students are actively involved in the learning process.

The cooperative learning model is a learning model that emphasizes collective attitudes or behaviors in working or helping each other in an orderly structure of cooperation in groups. This is in accordance with the opinion of Isjoni (2013) that the jigsaw cooperative learning model is not only superior in helping students understand difficult concepts, but is also very useful in fostering critical thinking skills, working together and helping friends. In the learning process students are actively involved, so that it has a positive impact on the quality of quality interaction and communication, and can motivate students to improve learning achievement. The jigsaw cooperative learning model requires students to be responsible individually as well as groups.

In the learning process the material is learned not only the material provided by the teacher, but students are also invited to provide and teach the material to other group members. Students are required to present the results of group work. In the presentation, students are encouraged to take an active role in responding to the group friends who presented the material. This situation supports students in their groups so they can learn to work together and responsibility until the success of the assignments in the group during the presentation.

This learning model is seen as a learning model that can motivate students to study the material well (Slavin Robert E, 2008). The form of motivated students is shown in the visual, oral, listening, writing, drawing, metric (measuring), mental and emotional aspects. This learning model is able to encourage students to be responsible for other people's own learning. Each group member is responsible for the success of his group and the completeness of the material being studied. Students not only learn the material themselves, but must be ready to teach the material they are learning to other friends in their group. Then the character of responsibility for learning will be strong. This is in accordance with one principle of jigsaw cooperative learning proposed by Miftahul Huda (2014), in cooperative learning students have two responsibilities, 
namely working on / understanding the material / tasks for the success of themselves and their group members.

In learning activities using the jigsaw cooperative model, each student in the expert group delivers learning material to other friends in the home group at the same time, so this causes a noisy classroom atmosphere and makes the classroom environment less conducive. In addition, there is an active movement of students from the original group to the expert group and back again to the original camp with a limited time, allowing the classroom environment to become messy. Thus in learning activities like this students can be required to be responsible for the classroom environment as well as possible. This description is in accordance with the opinion expressed by Slavin Robert E. (2008), the jigsaw cooperative learning model, students work in heterogeneous teams.

\section{CONCLUSIONS}

Based on data analysis and hypothesis testing, it can be concluded that there is a positive and significant effect of the application of the jigsaw cooperative learning model on science learning activities in grade IV SDN 12 Entikong. Based on the $t$ test with SPSS 24 and the test using the formula, it was obtained that the $t_{\text {observasi }}>t_{\text {tabel }}$ was $3,063>2,02$ (at the 5\% significant level) and 3,063 > 2,271 ((at the 1\% significance level) with a significance probability value $<0,05$ that 0,004 . While the magnitude of the influence of the application of the jigsaw cooperative learning model on the learning activities of fourth grade students of SDN 12 Entikong in science subjects is 2,55. This is based on the analysis using SPSS 24, it was found that the average score in the experimental class was 82,55 while the control class was 80,00 .

\section{ACKNOWLEDGEMENTS (OPTIONAL)}

Researchers would like to thank STKIP Melawi and SDN 12 Entikong for their support and assistance in the results of this study.

\section{REFERENCES}

Agus Suprijono. (2013). Cooperative Learning Teori dan Aplikasi Paikem. Yogyakarta: Pustaka Pelajar

Hendy Purnomo. (2016). Pengaruh Metode Jigsaw Terhadap Prestasi Belajar Siswa Mata Pelajaran. UNY: Yogyakarta. http://eprints.uny.ac.id/id/eprint/40510

Isjoni. (2013). Pembelajaran Kooperatif Meningkatkan Kecerdasan Komunikasi Antar Peserta Didik. Yogyakarta: Pustaka Pelajar.

Main Sufanti. 2010. Strategi Pembelajaran Bahasa Indonesia. Surakarta: Yuma Pustaka.

Maya Nurfitriyanti. (2017). Pengaruh Model Pembelajaran Kooperatif Tipe Jigsaw Terhadap Hasil Belajar Matematika ditinjau dari Kecerdasan Emosional. Jurnal Ilmiah Pendidikan MIPA, 7(2), 153-162. http://dx.doi.org/10.30998/formatif.v7i2.2229

Miftahul Huda. (2014). Cooperative Learning Metode, teknik, Struktur dan Model Penerapan. Yogyakarta: Pustaka Pelajar 
JIEES : Journal of Islamic Education at Elementary School Homepage : http://jiees.alkhoziny.ac.id/index.php/jeies Email : jiees@alkhoziny.ac.id
p-ISSN : 2723 -7184 ; e-ISSN : 2723-8148 JIEES, Vol. 1, No.2, Desember 2020 : 83-89 (c) 2020 JIEES : Journal of Islamic Education at Education Schoo

Mustofa. 2012. Penerapan Model Pembelajaran Kooperatif Tipe Jigsaw Sebagai Upaya Meningkatkan Aktivitas Belajar IPA Peserta Didik Kelas VII E Semester II pada Tema Pencemaran Air di SMP N 4 Wates UNY: Yogyakarta. http://eprints.uny.ac.id/id/eprint/8166

Sardiman. (2014). Interaksi dan Motivasi Belajar Mengajar. Jakarta: Rajawali Press.

Slavin, Robert E. (2008). Cooperative Learning Teori, Riset dan Praktik (terjemahan). Bandung: Nusa Media.

Sumiati dan Asra. (2007). Metode Pembelajaran. Bandung: Wacana Prima.

Taseman, Iman Rasiman, Arumi Puji Lestari, Atik Anturichana, Hanyfa Maulidiyah, H. H. (2020). IMPLEMENTASI EVALUASI SOAL PEMBELAJARAN IPS THE IMPLEMENTATION OF LEARNING EVALUATION ON SOCIAL STUDIES BASED ON 2013 CURRICULUM AT MI ASSYAFI' IYAH. AULADUNA: Jurnal Pendidikan Dasar Islam, 7(1), 74-80

Taseman. (2020). Pemanfaatan Media Visual Pada Pembelajaran IPS Di MI Darul Mutaallimin Sidoarjo. BADA'A: Jurnal Ilmiah Pendidikan Dasar, 2(1), 86-97.

Trianto. 2011. Mendesain Model Pembelajaran Inovatif-Progresif. Jakarta: Kencana Prenada Media Group.

Widy Dyah Mulyani. 2015. Pengaruh Penerapan Model Pembelajaran Kooperatif Tipe Jigsaw Terhadap Karakter Tanggung Jawab Pada Pembelajaran Pkn Siswa Kelas V SD N Sendangadi 1 Mlati UNY: Yogyakarta. http://eprints.uny.ac.id/id/eprint/28901

Wina Sanjaya. 2010. Strategi Pembelajaran Berorientasi Standar Proses Pendidikan. Jakarta: Kencana Prenada Media Group.

Yunus Abidin. 2014. Desain Sistem Pembelajaran Dalam Konteks Kurikulum 2013. Jakarta: Refika Aditama

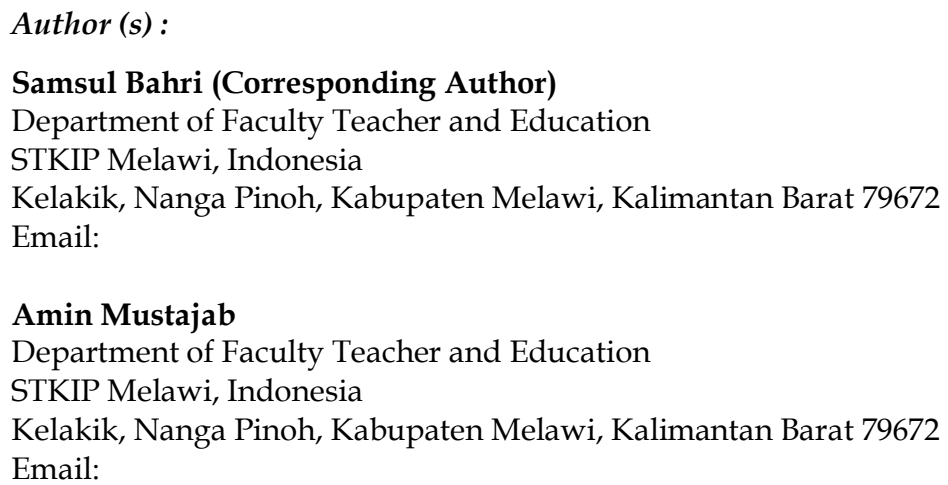

